\title{
The potential impacts of low and high salinities on salinity tolerance and condition index of the adult pearl oyster Pinctada imbricata radiata (Leach, 1814)
}

Ragia Moussa Moussa

\begin{abstract}
Background: Salinity is one of the most consequential environmental stressors affecting marine organisms. Knowledge of salinity tolerance is of particular value to aquaculture. However, little is known explicitly about the salinity tolerance of oyster adult stage. The present study was designed to elucidate the salinity tolerance range of Pinctada imbricata radiata in order to determine the appropriate locations for grow out phase of pearl oyster culture and to assess the possibility of applying new "low salinity post-operative care" method that greatly enhance the pearl quality after implantation. The effects of extremely low and high salinities were quantified on the adult oyster survival and the ecophysiological state. Oysters were experimented in acclimated and non-acclimated sets in salinities ranged from 10 to 55 ppt (part per thousand).

Results: It was found that the pearl oyster has a wide tolerance range of salinity. Within the optimal salinity range (25-38 ppt), no mortality was recorded. The mortality was significantly decreased and ceased in acclimated group as compared to non-acclimated in different ranges of salinities. Condition index (Cl) of oysters reared in different salinities after acclimation and without acclimation showed considerable variations in particular, at low salinities.

Conclusions: It is concluded that $P$. imbricata radiata can be reared in salinities up to 50 ppt during the growth phase. Low salinity post-operative care method can be applied on $P$. imbricata radiata after implantation by immersion in low salinities ranged between 20 and 25 ppt.
\end{abstract}

Keywords: Pinctada imbricata radiata, Pearl oyster, Salinity tolerance, Condition index, Pearl production

\section{Background}

Pinctada imbricata radiata is one of the most economically important oyster species that has successfully spread throughout the Mediterranean Sea, colonizing new habitats and becoming very abundant in the Levantine basin (Barash \& Danin, 1992; Galil \& Zenetos, 2002; Gofas \& Zenetos, 2003). It has been imported for aquaculture purposes in some parts of the Mediterranean Sea (Zenetos et al., 2004). It has considerable value of pearls and nacre or "mother of pearl" in addition to their edible flesh (Yassien, El-Ganainy, \& Hasan, 2009). It was the greatest source of natural pearls in the world, since

Correspondence: ragiamoussa@yahoo.com.au

Aquaculture Division, National Institute of Oceanography and Fisheries, Alexandria, Egypt

Springer Open ancient times (Almatar, 1992). Studies on the Mediterranean populations of $P$. imbricata radiata were performed in Tunisia, Turkey, and Egypt. They have focused on biometry, reproduction, seed implantation, and demographic features (Moussa, 2013; Moussa et al., 2014; Deidun, Gianni, Cilia, Lodola, \& Savini, 2014).

Salinity is considered one of the most consequential environmental stressors for marine bivalves (Miller, Ruiz, Minton, \& Ambrose, 2007; de Albuquerque, Ferreira, Salvador, \& Turini, 2012). In accordance with Verween, Vincx, and Degra (2007), an organism capacity to survive in an environment is restricted by its tolerance limits towards the different abiotic factors. Hence, the results of tolerance can be of particular value to aquaculture. As salinity optima are applicable in 
hatcheries, tolerance limits knowledge is necessary in selecting sites for different phases of pearl oyster culture (O'Connor \& Lawler, 2004). Pearl oysters of the genus Pinctada are euryhaline and able to live in waters of a wide range of salinity (Dame et al., 2002). Surprisingly, few data are available for adult oyster's tolerance; of this, most are based on field observations or laboratory studies of larval stages with a very limited salinity range.

According to the increase in importance of $P$. imbricata radiata as being a candidate species for Egyptian mariculture and pearl production (Moussa, 2013), salinity tolerance studies will be of considerable necessity. Knowledge of $P$. imbricata radiata tolerance limits to high salinity will provide needed information in selecting sites for its grow-out and preoperative conditioning phases. In the context of pearl production, the recent Egyptian studies of $P$. imbricata radiata provide information about the optimum oyster size and the best time for seed implantation (Moussa, 2013, Moussa, El Salhia, \& Khalifa, 2014). Few years ago, a new post-operative care method was developed by Atsumi, Ishikawa, Inoue, Ishibashi, and Komaru (2011) on P. fucata through oyster immersion in low salinity just after implantation. This method resulted in a significantly higher proportion of high-quality pearls than those oysters that were immersed in the sea. Study of $P$. imbricata radiata tolerance limits to low salinity will be useful in determining the best lowest salinity for oyster immersion in postoperative period.

Therefore, the present study was designed to elucidate the salinity tolerance range of $P$. imbricata radiata in order to determine the appropriate locations for growout phase and to assess the possibility of applying the "low salinity post-operative care" method that greatly enhance the pearl quality after implantation.

\section{Methods}

\section{Samples collection and maintenance}

A total of 480 Pinctada imbricata radiata samples $(54 \mathrm{~mm}$ mean dorso-ventral length, $41 \mathrm{~mm}$ mean hinge length, and $16.5 \mathrm{~mm}$ mean thickness) were collected from Abu Quir, Alexandria, at $20 \mathrm{~m}$ depth. Upon arrival, they were scrubbed to remove epibionts. The oysters were kept for 1 week in fiberglass tanks (ton) with filtered $(1 \mu \mathrm{m})$ seawater at $38 \mathrm{ppt}$ and $25{ }^{\circ} \mathrm{C}$. Oysters were fed daily ad libitum with cultured phytoplankton species (mixture of Isochrysis galbana and Chaetoceros sp.). Every second day, the water in each aquarium was exchanged.

\section{Experimental design}

Oysters were divided randomly into 48 groups of 10 samples, and each group was placed in separate $7 \mathrm{~L}$ aerated aquaria. The aquaria were divided into two sets; acclimated and non-acclimated. Each set has 24 aquaria filled with different low and high salinities $(10,15,20$, $25,38,45,50$, and $55 \mathrm{ppt}$ ) in three replicates.

Experimental high salinities were prepared by adding sodium chloride, whereas addition of fresh water to normal sea water was done for obtaining the low salinities. The fraction of the added fresh water can be calculated from the following formula:

$$
\text { Fraction of fresh water needed }=V-V\left[\frac{\mathrm{S}_{\text {final }}}{\mathrm{S}_{\text {initial }}}\right]
$$

where $V=$ volume of desired final salinity; $S_{\text {initial }}=$ initial salinity in the tank; and $S_{\text {final }}=$ desired final salinity.

In acclimated set, salinity was decreased gradually from normal sea water salinity $(38 \mathrm{ppt})$ to different low salinities $(10,15,20$, and $25 \mathrm{ppt})$ over the period of 7-12 days. On the other hand, salinity was increased from 38 ppt to different high salinities (45, 50 , and $55 \mathrm{ppt}$ ) over the period of 4-9 days. The rate of salinity decrease/increase was $2 \mathrm{ppt} /$ day. Acclimation in all treatments of acclimated set was achieved without mortality. In non-acclimated set, oysters were kept in 38 ppt then transferred abruptly to low (10, 15, 20, and $25 \mathrm{ppt}$ ) and high salinities (45, 50, and $55 \mathrm{ppt}$ ). Acclimated and non-acclimated oysters were kept at different salinities for 30 days.

Oysters were observed daily for survival. Dead animals were counted and removed according to the prescription of fail to respond to gentle probing of the mantle and gills by either closing their valves or withdrawing the mantle.

At the end of experimental period, the remaining oysters at different salinities were shucked. The separated flesh and shell valves of each oyster sample were dried at $80{ }^{\circ} \mathrm{C}$ in pre-weighed aluminum foil crucibles to constant weight. The dry flesh weights were measured using an electric balance with 0.01 precision. The condition index (CI) was determined as the ratio of dry tissue weight to the dry shell weight according to the following formula:

The condition index $\%(\mathrm{CI})=[$ dry meat weight $/$ dry shell weight $\times 100]$ (Crosby \& Gale, 1990).

\section{Statistical analysis}

Data were analyzed using IBM SPSS software package version 20.0. Quantitative data were described using mean and standard deviation. Significance of the obtained results was judged at the 5\% level. Student's $t$ test was used to compare between acclimated and nonacclimated groups, whereas $F$ test (ANOVA) was applied to compare between different salinities, and post hoc test (LSD) was for pairwise comparisons. 


\section{Results}

\section{Salinity tolerance}

The mortality rate of oysters was significantly different within acclimated (ANOVA: $F=143.524, P<0.001$ ) and non-acclimated (ANOVA: $F=1137.142, P<0.001$ ) sets. At 10 and $15 \mathrm{ppt}$, total mortality was observed in non-acclimated set, while mortality of acclimated oysters was significantly decreased $(P<0.001)$ to 82.7 , and $75 \%$, respectively (Table 1). At $20 \mathrm{ppt}$, high-mortality percentage of $96 \%$ in non-acclimated oysters was recorded, compared to $66 \%$ mortality rate in acclimated set. No mortality was observed in 25 ppt in both acclimated and non-acclimated sets (Fig. 1).

The significant difference of mortality rates between acclimated and non-acclimated sets was also recorded in the all tested high salinities, $45 \mathrm{ppt}(P=0.001), 50 \mathrm{ppt}$ $(P=0.023)$, and 55 ppt $(P=0.004)$ (Table 1$)$. No mortality was observed in acclimated oysters at $45 \mathrm{ppt}$, whereas $16.3 \%$ mortality was recorded in non-acclimated ones. At $50 \mathrm{ppt}$, mortality rate reached $49 \%$ in non-acclimated oysters and was declined to $36.7 \%$ in acclimated ones. Non-acclimated oysters attained total mortality at 55 ppt, while it was $51 \%$ in acclimated oysters (Fig. 2).

\section{Condition index}

In acclimated group, significant differences of $\mathrm{CI}$ values were observed among low salinities (ANOVA: $F=35.268$, $P<0.001)$. However, no differences were noticed between CI values in 38 and 25 ppt. On the other hand, CI was significantly dropped from 6.5 in sea water (38 ppt) to 3.3 in 15 ppt $(P<0.001)$ and 4.5 in 20 ppt $(P=0.003)$ (Fig. 3$)$. Similarly, sharp decline was significantly observed $(P<$ 0.001 ) in 10 ppt with CI values of 1.9. In high salinities, CI showed a significant difference within the tested salinities (ANOVA: $F=26.369, P<0.00$ ). Estimated $\mathrm{CI}$ at $45 \mathrm{ppt}$ (5.8) was close to that recorded at 38 ppt (6.5), while CI values at 50 and $55 \mathrm{ppt}$ showed a significant decline recording 3.7 and 2.98, respectively (Fig. 4).

CI could not be calculated in non-acclimated groups of 10,15 , and 55 ppt because of total mortality. For non-

Table 1 Mean of mortality rates \pm SD of Pinctada imbricata radiata after 30-day exposure to different salinities in acclimated and non-acclimated sets

\begin{tabular}{lllll}
\hline Salinity (ppt) & Acclimated & Non-acclimated & $t$ & $p$ \\
\hline 10 & $82.7 \pm 2.5$ & $100.0 \pm 0.0$ & $11.930^{*}$ & $<0.001^{*}$ \\
15 & $75.0 \pm 1.0$ & $100.0 \pm 0.0$ & $43.301^{*}$ & $<0.001^{*}$ \\
20 & $66.7 \pm 7.6$ & $96.0 \pm 3.6$ & $6.016^{*}$ & $0.004^{*}$ \\
25 & $0.0 \pm 0.0$ & $0.0 \pm 0.0$ & - & - \\
45 & $0.0 \pm 0.0$ & $16.3 \pm 3.1$ & $9.260^{*}$ & $0.001^{*}$ \\
50 & $36.7 \pm 4.7$ & $49.0 \pm 3.6$ & $3.594^{*}$ & $0.023^{*}$ \\
55 & $51.0 \pm 5.3$ & $100.0 \pm 0.0$ & $16.039^{*}$ & $0.004^{*}$ \\
\hline
\end{tabular}

*Statistically significant at $p \leq 0.05$

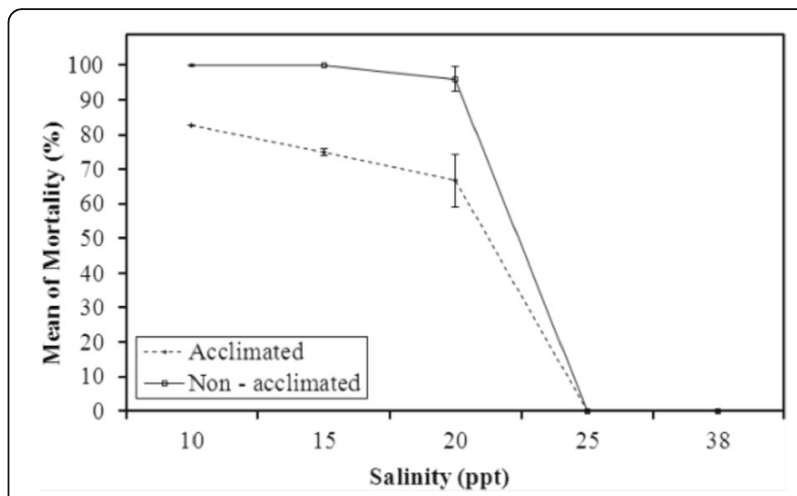

Fig. 1 Mortality rates of Pinctada imbricata radiata after 30-day exposure to different low salinities in acclimated and non-acclimated sets

acclimated groups, CI was only estimated in 20, 25, 40, and $50 \mathrm{ppt}$ that showed significant difference among each other (ANOVA: $F=33.901, P<0.001$ ). Estimated $\mathrm{CI}$ at $20 \mathrm{ppt}(P=0.14)$ and $25 \mathrm{ppt}(P=0.67)$ showed no significant difference between acclimated and nonacclimated groups. However, CI values in nonacclimated group of $45(P<0.001)$ and 50 ppt $(P=0.011)$ were significantly lower than those in acclimated ones (Table 2, Fig. 3).

\section{Discussion}

Salinity is among the most important factors influencing the biology and physiology of oysters that are wellknown for their broad tolerance of salinity (0 to 42 ) (Galstoff, 1964). Oysters need to be specifically explored to properly understand, manage, and predict the responses of their populations (Rybovich, 2014). In the present study, $P$. imbricata radiata from Egyptian Mediterranean coast has been found to tolerate a wide range of salinity from 10 to $55 \mathrm{ppt}$. This finding indicated that tolerance to low salinities was wider than that to high salinities. This may be attributed to the physiological performance of oyster at lower salinities as they exhibited partial or complete contraction of adductor

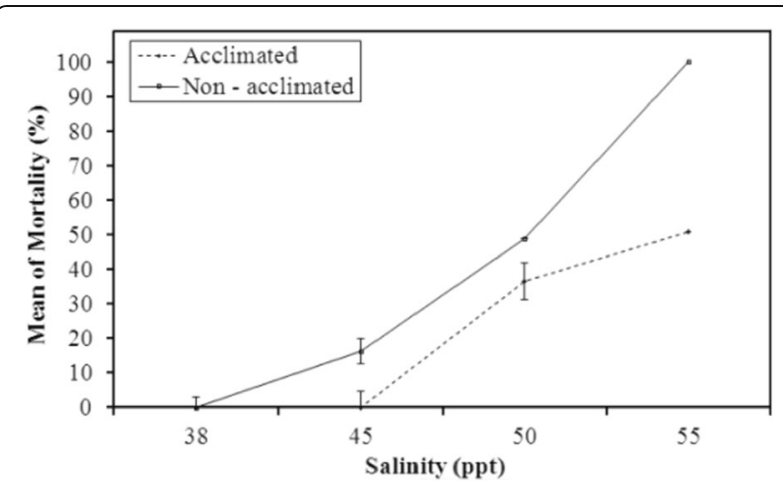

Fig. 2 Mortality rates of Pinctada imbricata radiata after 30-day exposure to different high salinities in acclimated and non-acclimated sets 


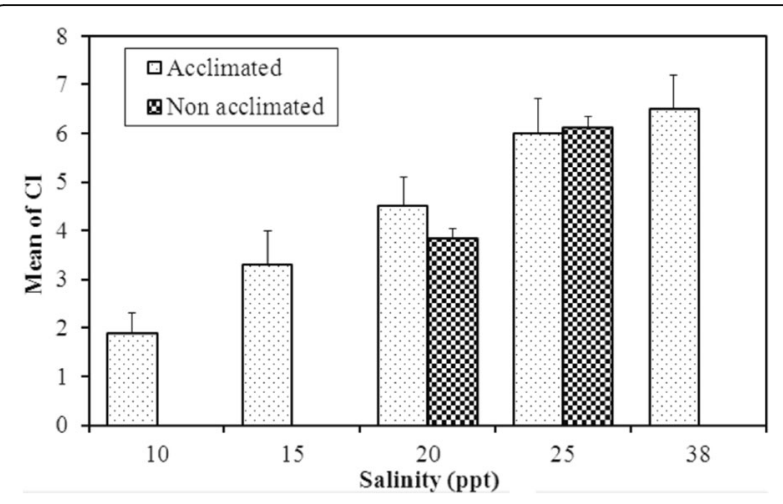

Fig. 3 Condition index (Cl) of acclimated and non-acclimated Pinctada imbricata radiata after 30-day exposure to different low salinities

muscles and a slowing or cessation of water current through the gills as suggested by Newell (1985).

Many studies have quantified and modeled the effects of salinity on the larval stages such as in Crassostrea iredalei (Fang, Peng, Yen, Yasin, \& Hwai, 2016) and Saccostrea glomerata (Dove \& O'Connor, 2007). Although it is essential to understand the potential impacts of salinity on adult oyster resources in order to adapt and manage for long-term sustainability, scarce studies were available. Quast, Johns, Pitts, Matlock, \& Clark, (1988) reported that the oyster optimum salinity range is 14 to $28 \mathrm{ppt}$. However, the optimal salinity for C. virginica was 10-28 ppt (Wilson et al., 2005). In the present study, $P$. imbricata radiata optimal salinity range yielding no mortality was found at $25-38$ ppt. No mortality occurred in the optimal salinity range due to ability of oyster cells to remain functional without losing water and shrinkage through accumulation of amino acids (FAA) to offset the increasing extracellular osmotic pressure (Findley, Belisle, \& Stickle, 1978). Outside the optimal salinity range, mortality rates were expected to be attained in accordance with more exerted salinity stress.

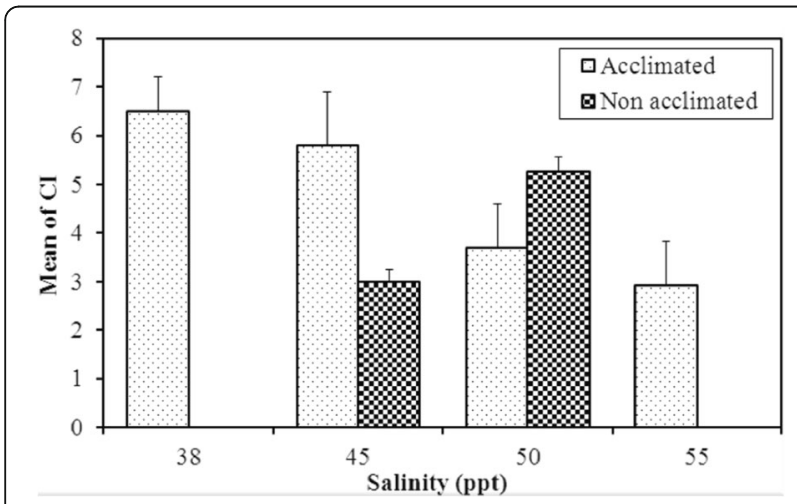

Fig. 4 Condition index (Cl) of acclimated and non-acclimated Pinctada imbricata radiata after 30-day exposure to different high salinities
Table 2 Mean of $\mathrm{Cl} \pm$ SD of Pinctada imbricata radiata after 30-day exposure to different salinities in acclimated and non-acclimated sets

\begin{tabular}{lllll}
\hline Salinity (ppt) & Acclimated & Non-acclimated & $t$ & $p$ \\
\hline 10 & $1.9 \pm 0.4$ & - & - & - \\
15 & $3.3 \pm 0.7$ & - & - & - \\
20 & $4.5 \pm 0.6$ & $3.83 \pm 0.21$ & 1.664 & 0.140 \\
25 & $6.0 \pm 0.7$ & $6.13 \pm 0.21$ & 0.441 & 0.673 \\
38 & $6.5 \pm 0.5$ & - & - & - \\
45 & $5.8 \pm 1.1$ & $3.0 \pm 0.26$ & $7.289^{*}$ & $<0.001^{*}$ \\
50 & $3.7 \pm 0.9$ & $5.27 \pm 0.31$ & $3.042^{*}$ & $0.011^{*}$ \\
55 & $2.93 \pm 0.89$ & - & - & - \\
\hline
\end{tabular}

*Statistically significant at $p \leq 0.05$

In the present study, mortality rates at 20 ppt were $66 \%$ in acclimated set over 30 days. However, in Australia, previous studies have shown that $P$. imbricata radiata attained high mortality at salinities of 22-26 ppt (O'Connor \& Lawler, 2004). Similarly, in India, bulk of $P$. imbricata mortality was reported after 3 days in 24 ppt (Alagarswami \& Victo, 1987; Dharmaraj, Kandasami, \& Alagarswami, 1987). This geographic difference of tolerance limits within species was early mentioned by Pierce, Rowland-Faux, and O'Brien (1992) who attributed the geographic difference in oyster salinity tolerances to the biochemical difference which may reflect the genetic difference.

From a commercial perspective, the present findings of Egyptian $P$. imbricata radiata tolerance of low salinities have many applicable aspects such as infection prevention and pearl production. With regard to oyster infection, Fisher and Newell (1986) pointed out that high salinity reduces the oysters' defense capacity and leaves them more susceptible to pathogenic parasites. Therefore, infections can be rejected by transfer from high to low salinities (Haskin \& Ford, 1982). In the light of the present results, $P$. imbricata radiata can be transferred into $25 \mathrm{ppt}$ for long periods and into $10-20 \mathrm{ppt}$ for short time to reject infection of many diseases. In the context of pearl production, it is known that pearl oyster grafting is a complex crucial surgical operation affecting the pearl formation and resulting in post-grafting mortality, nucleus rejection, and unreliable pearl quality that greatly affect the farm profitability. Few years ago, Atsumi et al. (2011) have developed a new post-operative care method in order to improve graft performance and yield. They immersed oysters in low salinity ( $25 \mathrm{ppt}$ ) seawater just after implantation. It resulted in a significantly higher proportion of high-quality pearls than those from oysters that were immersed in the sea. With considering $P$. imbricata radiata as a candidate for Egyptian pearl production, the present findings suggest that it can be immersed in not lower than 25 ppt to avoid mortality occurrence. 
Two-way ANOVA showed an overall highly significant effect of acclimation $(P \leq 0.05)$ on mortality of $P$. imbricata radiata with salinities 10 and 55 ppt. In $10 \mathrm{ppt}$, the acclimation showed a considerable effect on decreasing the total mortality in acclimated set to $82 \%$ over 30 days. As wise, at $55 \mathrm{ppt}$, the mortality was 100 and $51 \%$ in non-acclimated and acclimated sets, respectively. This finding is in agreement with the previous work of Fisher and Newell (1986), who mentioned that the osmotic adjustment process is fastest at the acclimation salinities and slowed with acute change in salinity.

The present study investigated the condition index (CI) as being an indicator of general oyster health as reported by Heilmayer, Digialleonardo, Qian, \& Roesijadi, (2008). Furthermore, CI is a rapid measure of ecophysicological state (Lucas \& Beninger, 1985; Yıldız \& Lök, 2005) and considered as an economic indicator of market products (Orban et al., 2002). By clarifying changes of condition index of oysters at extreme low and high salinities, it will be possible to predict and manage sustainable oyster populations. In $P$. imbricata radiata, CI was previously estimated as monthly values for the mantle, gill, adductor muscle, and gonad-visceral mass tissues to determine the best time of implantation surgery (Moussa et al., 2014). In the present study, CI was estimated to investigate the overall oyster health after acclimation to different salinities (Figs. 3 and 4). It was observed that $\mathrm{CI}$ values decrease as the salinity difference increase. Within the optimal range 25-38 ppt, there was no significant decrease in CI values. As wise, the low recorded mortality at $45 \mathrm{ppt}$ (16\%) was coinciding with little declined CI values. On the other hand, CI was gradually declined in high salinities, while it was sharply decreased in low salinities. This finding may be due to induction of metabolic depression state through prolonged valve closure as mentioned by Kennedy (1991). During the close-valve stage, anaerobiosis is induced (Lannig, Cherkasov, Portner, Bock, \& Sokolova, 2008), anaerobic end products accumulate, and a nearly complete cessation of feeding and gas exchange between the oyster and the external medium occurred (Michaelidis, Haas, \& Grieshaber, 2005). This behavioral or physiological change of valve closure in response to salinity change was suggested to allow isoosmotic intracellular regulation to commence (Hawkins \& Bayne, 1992), and it was observed previously by Alagarswami and Victo (1987) in P. imbricata.

\section{Conclusions}

It is concluded that $P$. imbricata radiata can tolerate a wide range of salinity. It can be reared in salinities up to 55 ppt during the grow-out phase. Low salinity postoperative care method for enhancing the pearl quality can be applied on $P$. imbricata radiata after implantation. Oysters can be immersed in low salinities within
20-25 ppt range. Acclimation should be applied before transferring oysters to different salinities.

\section{Abbreviations}

Cl: Condition index; ppt: Part per thousand; psu: Practical salinity unit

\section{Acknowledgements}

The author thanks Mrs. Essra Ali for her efforts in samples maintenance.

Funding

No funding for the present study.

Availability of data and materials

The dataset supporting the conclusions of the present article is included within the article and its additional files.

\section{Authors' contributions}

The author read and approved the final manuscript.

\section{Authors' information}

I studied zoology in Alexandria University, Egypt. I have obtained a MSc. in brackish water shrimp culture and Ph.D. in sea cucumber culture from the University of Tanta, Egypt. Currently, I am a researcher at Invertebrate Aquaculture Laboratory, Aquaculture Division, National Institute of Oceanography and Fisheries, Alexandria, Egypt. I have several peer reviewed publications in national and international journals. I collaborate in several research projects. I serve on the editorial board of many open-access peer reviewed scientific journals. I refereed scientific papers under potential publication in different national and international peer-reviewed scientific journals. My research focused in shrimp culture and sea cucumber culture. Thereinafter, my researches were directed to identification of invasive species in Egyptian Mediterranean waters through being a principle investigator for a project entitled " patterns of diversity and climate change in Mediterranean transition zone" that supported by IDRC-Canada. My latest researches focused in pearl oyster culture and pearl production.

\section{Ethics approval and consent to participate}

The study was complying with national and international guidelines that approved by an appropriate ethics committee such as the International Council for Laboratory Animal Science (ICLAS) and the revised Animals (Scientific Procedures) Act 1986 in the UK and Directive 2010/63/EU in Europe.

Consent for publication

Not applicable

\section{Competing interests}

The author declares no competing interests.

\section{Publisher's Note}

Springer Nature remains neutral with regard to jurisdictional claims in published maps and institutional affiliations.

Received: 9 June 2017 Accepted: 5 January 2018

Published online: 12 February 2018

References

Alagarswami, K., \& Victo, A. C. C. (1987). Salinity tolerance and rate of filtration of the pearl oyster Pinctada fucata. Journal of the Marine Biological Association of India., 18, 149-158.

Almatar, S. (1992). Status of the pearl oyster fishery of Kuwait. SPC Pearl Oyster Information Bulletin., 5, 22-23.

Atsumi, T., Ishikawa, T., Inoue, K., Ishibashi, R., \& Komaru, A. (2011). Improvement of the production of high-quality pearls by keeping post-operative pearl oysters Pinctada fucata in low-salinity seawater. Nihon-suisan-gakkai-shi, 77(1), 68-74.

Barash, A., \& Danin, Z. (1992). Fauna Palaestina. Mollusca 1: Annotated list of Mediterranean molluscs of Israel and Sinai, (405). Jerusalem: Israel Academy of Science and Humanities. 
Crosby, M. P., \& Gale, L. D. (1990). A review and evaluation of bivalve condition index methodologies with a suggested standard method. Journal of Shellfish Research., 9(1), 233-237.

Dame, R. D., Bushek, D., Allen, D., Koepfler, E., Lewitus, A., \& Edwards. (2002), Ecosystem response to bivalve density reduction: Management implications. Aquatic Ecology., 36(1), 51-65.

de Albuquerque, M. C. P., Ferreira, J. F., Salvador, G. C., \& Turini, C. (2012). Influence of temperature and salinity on survival and growth of the pearl oyster larvae Pteria hirundo. Boletim do Instituto de Pesca., 38(3), 189-197.

Deidun, A., Gianni, F., Cilia, D., P., Lodola, A., \& Savini, D. (2014). Morphometric analyses of a Pinctada radiata (Leach, 1814) (Bivalvia: Pteriidae) population in the Maltese Islands. Journal of Black Sea/Mediterranean Environment., 20(1), 1-12.

Dharmaraj, S., Kandasami, D., \& Alagarswami, K. (1987). Some aspects of physiology of pearl oyster. In K. Alagarswami (Ed.), Pearl Culture, (vol. 39, pp. 21-28). Bulletin Central Marine Fisheries Research Institute.

Dove, M. C., \& O'Connor, W. A. (2007). Ecotoxicological evaluations of common hatchery substances and procedures used in the production of Sydney rock oysters Saccostrea glomerata (Gould 1850). Journal of Shellfish Research., 26, 501-508.

Fang, A., Peng, T. C., Yen, P. K., Yasin, Z., \& Hwai, A. (2016). Effect of salinity on embryo and larval development of oyster Crassostrea iredalei. Tropical Life Science Research., 27(1), 23-29.

Findley, A. M., Belisle, B. W., \& Stickle, W. B. (1978). Effects of salinity fluctuations on the respiration rate of the southern oyster drill Thais haemastoma and the blue crab Callinectes sapidus. Marine Biology, 49, 59-67.

Fisher, W. S., \& Newell, I. E. I. (1986). Salinity effects on the activity of granular hemocytes of American oyster, Crassostrea virginica. Biological Bulletin., 170(1), 122-134.

Galil, B. S., \& Zenetos, A. (2002). A sea change, exotics in the eastern Mediterranean Sea. In E. Leppäkoski, S. Gollasch, \& S. Olenin (Eds.), Invasive aquatic species of Europe, distribution, impacts and management, (pp. 325336). Dordrecht: Kluwer Academic Publishers.

Galstoff, P. S. (1964). The American oyster Crassostrea Virginica. Fisheries Bulletin of the Fish and Wildlife Service, 64, 397-458.

Gofas, S., \& Zenetos, A. (2003). Exotic molluscs in the Mediterranean basin, current status and perspectives. Oceanography and marine biology., 41, 237-277.

Haskin, H., \& Ford, S. (1982). Haplosporidium nelsoni (MSX) on delaware bay seed oyster beds: A host-parasite relationship along a salinity gradient. Journal of Invertebrate Pathology., 40(3), 307-439.

Hawkins, A. J. S., \& Bayne, B. L. (1992). Physiological interrelations and the regulation of production. In E. Gosling (Ed.), The mussel Mytilus: Ecology, physiology, genetics and culture, (pp. 171-222). Amsterdam: Elsevier.

Heilmayer, O., Digialleonardo, J., Qian, L., \& Roesijadi, G. (2008). Stress tolerance of a subtropical Crassostrea virginica population to the combined effects of temperature and salinity. Estuarine, Coastal and Shelf Science., 79(1), 179-185.

Kennedy, V. S. (1991). American oyster, Crassostrea virginica. In S. L. Funderburk, S. J. Jordan, J. A. Mihursky, \& D. Riley (Eds.), Habitat requirements for Chesapeake Bay living resources, (2nd ed., pp. 3-20). Solomons: Chesapeake Research Consortium, Inc..

Lannig, G., Cherkasov, A., S., Portner, H., O., Bock, C., Sokolova, I., M. (2008). Cadmium dependent oxygen limitation affects temperature tolerance in eastern oysters (Crassostrea virginica Gmelin). American journal of Physiology. Regulatory, Integrative and Comparative Physiology. 294(4):1338-1346.

Lucas, A., \& Beninger, P. G. (1985). The use of physiological condition index in marine bivalve aquaculture. Aquaculture, 44(3), 187-200.

Michaelidis, B., Haas, D., \& Grieshaber, M. K. (2005). Extracellular and intracellular acid-base status with regard to the energy metabolism in the oyster Crassostrea gigas during exposure to air. Physiological and Biochemical Zoology., 78(3), 373-383.

Miller, A., W., Ruiz, G., M., Minton, M., S., \& Ambrose, R., F. (2007). Differentiating successful and failed molluscan invaders in estuarine ecosystems. Marine Ecology Progress Series., 332, 41-51.

Moussa, R. M. (2013). Biometric studies of growth pattern affecting pearl production in pearl oyster Pinctada radiata. Egyptian Journal of Zoology., 60, 397-414.

Moussa, R. M., El Salhia, M., \& Khalifa, A. (2014). Energy storage and allocation of pearl oyster Pinctada radiata (Leach, 1814) in relation to timing of pearl seeding. International journal of biology and biological sciences., 3(5), 053-066.

Newell, R. I. E. (1985). Physiological effects of the MSX parasite Haplosporidium nelsoni (Haskin, Stauber \& Mackinl on the American oyster Crassostrea cirginica (Gmelin)). Journal of Shellfish Resarch, 5, 91-95.

O'Connor, W., \& Lawler, F. (2004). Salinity and temperature tolerance of embryos and juveniles of the pearl oyster, Pinctada imbricata Röding. Aquaculture, 229, 493-506.
Orban, E., Di Lena, G., Nevigato, T., Casini, I., Marzetti, A., \& Caproni, R. (2002). Seasonal chances in meat continent and chemical composition of mussels (Mytilus galloprovincialis) cultured in two different Italian sites. Food Chemistry., 77(1), 57-65.

Pierce, S. K., Rowland-Faux, L. M., \& O'Brien, S. M. (1992). Different salinity tolerance mechanisms in Atlantic and Chesapeake Bay conspecific oysters: Glycine betaine and amino acid pool variations. Marine Biology, 113(1), 107-115.

Quast, W. D., Johns, M. A., Pitts, D. E., Matlock, G. C., \& Clark, J. E. (1988). Texas oyster fishery management plan source document, (p. 178). Austin: Texas Parks and Wildlife Department, Coastal Fisheries Branch.

Rybovich, M. M. (2014). Growth and mortality of spat, seed, and market-sized oysters (Crassostrea virginica) in low salinities and high temperatures. MSC. Louisiana State University.

Verween, A., Vincx, M., \& Degra, S. (2007). The effect of temperature and salinity on the survival of Mytilopsis leucophaeata larvae (Mollusca, Bivalvia):The search for environmental limits. Journal of Experimental Marine Biology and Ecology., 348(1-2), 111-120.

Wilson, C., Scotto, L., Scarpa, J., Volety, A., Laramore, S., \& Haunert, D. (2005) Survey of water quality, oyster reproduction and oyster health status in the St. Lucie Estuary. Journal of Shellfish Research., 24(1), 157-165.

Yassien, M. H., El-Ganainy, A. A., \& Hasan, M. H. (2009). Shellfish fishery in the north western part of the Red Sea. World Journal of Fish and Marine Sciences, 1(2), 97-104.

Yıldız, H., \& Lök, A. (2005). Meat yield of mussels (Mytilus galloprovincialis Lamarck, 1819) in different size groups in Kilya Bay-Dardanelles. Journal of Fisheries and Aquatic Sciences., 22(1), 75-78.

Zenetos, A., Dosi, A., Abatzopoulos, T., J., Triantafyllidis, A., Bejaoui, N., Soufi, E., et al. (2004). Study to investigate an invading bioindicator in the Mediterranean, Pinctada radiata (Leach, 1814). Communication presented at ICES/IOC/IMO Study group on Ballast and other ship vectors.

\section{Submit your manuscript to a SpringerOpen ${ }^{\circ}$ journal and benefit from:}

- Convenient online submission

- Rigorous peer review

- Open access: articles freely available online

- High visibility within the field

- Retaining the copyright to your article

Submit your next manuscript at $>$ springeropen.com 